http://dx.doi.org/10.12775/szhf.2021.005

\author{
DARIUSZ BARBASZYŃSKI \\ UNIWERSYTET WARMIŃSKO-MAZURSKI \\ E-MAIL: DARIUSZ.BARBASZYNSKI@UWM.EDU.PL \\ ORCID: 0000-0003-1734-9260
}

\title{
Specyfika poznania naukowego w refleksji Mariana Borowskiego
}

Warto przyjrzeć się bliżej dyskusji na temat specyfiki poznania naukowego prowadzonej w środowisku polskich filozofów w końcu XIX stulecia oraz w pierwszych dwóch dekadach wieku XX, a szczególnie założeniom koncepcji przedstawionej przez Mariana Borowskiego ${ }^{1}$. Myśliciel ten był jednym z najstarszych uczniów Kazimierza Twardowskiego w okresie kształtowania się etosu badawczego szkoły lwowskiej². Dlatego pogląd Borowskiego na istotę poznania naukowego ujawnia zarazem specyfikę dyskusji prowadzonych w tej kwestii w gronie najbliższych współpracowników Twardowskiego.

${ }^{1}$ O życiu i działalności naukowej Mariana Borowskiego pisałem już wcześniej w: Dariusz Barbaszyński, Odkrywanie struktur rzeczywistości. Problemy filozofii całości w poglądach Mariana Borowskiego (Olsztyn: Wydawnictwo Uniwersytetu Warmińsko-Mazurskiego, 2012), 235-242.

2 Etos badawczy szkoły lwowskiej ukształtował się już w latach 1895-1914, gdyż w tym okresie pojawiły się we Lwowie niezbędne składniki życia naukowego, takie jak: seminarium filozoficzne, pracownia psychologiczna, Polskie Towarzystwo Filozoficzne oraz Ruch Filozoficzny. 
Ocenę wartości poznania naukowego Borowski przedstawił w szerszym zakresie w następujących pracach publikowanych w latach 1910-1922: O filozofii Ryszarda Avenariusa; „Recenzja pracy W. Biegańskiego pt. Traktat o poznaniu i prawdzie"; Humanistyczne i empiryczne pierwiastki w nauce; O rozwoju życia psychicznego oraz Instynkt, intelekt, intuicja ${ }^{3}$.

W roku 1910 Borowski publikuje w trzech częściach artykuł O filozofi Ryszarda Avenariusa. Tytuł pracy jest nieco mylący, ponieważ filozof przedstawia w nim przede wszystkim własne stanowisko na temat istoty i statusu poznania naukowego w strukturze ludzkiej wiedzy ${ }^{4}$. Znajdziemy w nim jednak także krótką ocenę koncepcji Avenariusa ukazanej w jego rozprawie pt. Kritik der reinen Erfahrung 5 . Borowski zauważa tutaj, że pragnienie zrozumienia istoty danych doświadczalnych jest „[...] potężną dźwignią w rozwoju nauki. Pojęcia, zasady, teorie, hipotezy, tłumaczenia, nawet fikcje - są to środki, którymi posługuje się nauka na równi z eksperymentem i obserwacją celem odkrywania nowych faktów i stałych związków między zjawiskami”'. $\mathrm{W}$ poznaniu naukowym istotne jest więc odkrywanie prawidłowości i praw funkcjonujących w rzeczywistości przyrodniczej i społecznej człowieka. Borowski podkreślał jednak w tym artykule, że w realizacji celów naukowych kryje się niebezpieczeństwo absolutyzacji i nadmiernej formalizacji języka naukowego, który powinien być tylko narzędziem niezbędnym do opisu obiektywnej rzeczywistości. W nauce - akcentował - chodzi przecież

3 W dorobku naukowym Borowskiego znajdziemy również inne publikacje, w których pojawiają się jakieś odniesienia do problemów nauki, ale nie są to analizy dotyczące wprost specyfiki poznania naukowego. Zob. Marian Borowski, „Czy jednakowe skutki mogą być wywołane różnymi przyczynami?”, Przegląd Filozoficzny (1904): 105 (Autoreferat z odczytu Borowskiego przedstawionego we Lwowie w kółku filozoficznym w pierwszym półroczu 1904 r.); tegoż, „Krytyka pojęcia związku przyczynowego”, Przegląd Filozoficzny 4 (1907): 492-508; tegoż, „Recenzja pracy W. Kozłowskiego Systemat wiedzy i klasyfikacja nauk jako wstęp do wykształcenia ogólnego", Książka. Miesięcznik poświęcony krytyce i bibliografii polskiej 3 (1914): 138-139; tegoż, „Ernest Mach”, Gazeta Wieczorna (Lwów) 28 marca (1916).

4 Marian Borowski, „O filozofii Ryszarda Avenariusa”, Widnokręgi 17 (1910): 130-134; 18 (1910): 172-175; 19 (1910): 196-204.

5 Richard Avenarius, Kritik der reinen Erfahrung, t. 1, 2 (Leipzig: Verlag, 1888-1890).

${ }^{6}$ Borowski, „O filozofii” 18: 174. 
$\mathrm{w},[\ldots]$ ostatecznej linii o opanowanie konkretnego świata, a metaempiryczne pojęcia naukowe, hipotezy, teorie są to tylko środki do celu”.

W tym artykule Borowski pyta także o możliwość wykorzystania koncepcji „czystego doświadczenia” do uzasadnienia teorii naukowych. Sądzi, że nie można w sposób jednoznaczny ocenić znaczenia propozycji Ryszarda Avenariusa w historii nauki. $Z$ jednej strony ta teoria, jako ważny składnik empiriokrytycyzmu, przyczyniła się, zwłaszcza w Niemczech, do wzbudzenia żywej dyskusji na temat istoty poznania naukowego. $\mathrm{Z}$ drugiej strony „czyste doświadczenie” było tylko pewnym spektrum rozmaitych przeżyć świadomych, które jednak nie funkcjonowały w obrębie jakiejś stałej struktury poznawczej. Borowski stwierdza więc w konsekwencji, że „[...] metoda czystego doświadczenia nie może mieć większej wartości dla nauki, niż jej osławiona poprzedniczka z pierwszej połowy XIX wieku - uniwersalna metoda czystej spekulacji. Dzisiejsza nauka potrzebuje dla swojego rozwoju tak pracy doświadczalnej, jak i pracy myślowej. Posługuje się zarówno laboratoriami przyrodników, jak i tym najcenniejszym laboratorium, jakim jest mózg ludzki"8.

7 Borowski, „O filozofii” 17: 134. Definiując cel nauki jako dążenie do opanowania konkretnego świata, Borowski wyraźnie inspiruje się założeniami koncepcji nauki przedstawianej przez Kazimierza Twardowskiego na wykładach i później także w kilku jego pracach. W głośnym artykule z roku 1921 pt. „Symbolomania i pragmatofobia” Twardowski przestrzegał uczonych - zarówno przedstawicieli nauk przyrodniczych, jak i humanistów - przed iluzorycznością analiz dotyczących tylko przedmiotów idealnych (np. symboli). Podkreślał zdecydowanie, że „[...] używając symbolów i operując nimi, trzeba się ustawicznie jak najsumienniej liczyć z faktem, że odgrywają one rolę środka mającego wieść do wspomnianego celu. Trzeba więc symbolikę - wyrazem tym dla krótkości obejmujemy same symbole, jak dokonywane na nich działania - jak najdokładniej dostosowywać do pojęć i przedmiotów symbolizowanych, trzeba ją raz po raz poddawać surowej kontroli, by nie narazić się na trudności w końcowej interpretacji rezultatów, uzyskanej przy pomocy symboliki i w jej języku wyrażonych”, w: Kazimierz Twardowski, „Symbolomania i pragmatofobia” (Odczyt wygłoszony na 216 posiedzeniu naukowym Polskiego Towarzystwa Filozoficznego dnia 6 marca 1921 r.), Ruch Filozoficzny 6, 1-2 (1921-1922): 2. Zob. tegoż, „Nauki humanistyczne a psychologia” (Autoreferat z odczytu wygłoszonego we Lwowie w dniu 12 października 1912 r. na posiedzeniu Polskiego Towarzystwa Filozoficznego), Ruch Filozoficzny 9 (1912).

8 Borowski, „O filozofii” 18: 175. W innym kontekście o specyfice poznania naukowego pisze w kolejnej pracy z roku 1910. Borowski twierdzi, że wszelka aktywność poznawcza, której rezultatem jest teoria naukowa „[...] opiera się na konstatowaniu faktów danych nam w teraźniejszości. Historyk bada istniejące obecnie dokumenty i pomniki, by móc wnioskować 
Do rozważań o istocie nauki powróci Borowski kilka lat później. W 1913 roku wygłasza bowiem we Lwowie odczyt pt. „Humanistyczne i empiryczne pierwiastki w nauce", który został też opublikowany jako osobna rozprawa ${ }^{9}$. Opisuje w nim szczegółowo strukturę wiedzy naukowej. Sugeruje, że składa się ona z trzech składników, czyli „[...] z części heurystycznej, tj. obserwacji kierowanej hipotezami, z części systematycznej, która stanowi tworzenie klasyfikacji i praw, oraz z części praktycznej, dbającej o zastosowanie wyników naukowych do przekształcania rzeczywistości. Innymi słowy podsumowuje Borowski - dzielimy każdą naukę na jej część empiryczną, na teoretyczną (do której należy też część filozoficzna) oraz na jej część stosowaną"10.

Uczony sądził, że w strukturze poznania naukowego trzeba także uwzględnić dwa inne, istotne składniki - humanistyczny i empiryczny. Borowski nazywa je pierwiastkami wiedzy naukowej i twierdzi, że obydwa składniki równoważą się i przenikają wzajemnie. Kontekst humanistyczny naukowej aktywności człowieka ujawnia się w pięciu regułach: zasadzie wyboru, ekonomii, wyjaśnienia, pewności oraz regule harmonii ${ }^{11}$. Można powiedzieć, że konieczność stosowania tych reguł w poznaniu naukowym wynika z istnienia określonych, przyrodzonych cech ludzkiej natury czy - mówiąc ściślej - pew-

o przyszłości, fizyk bada obecny stan systemów fizycznych, aby przepowiedzieć jego stan w przyszłości. Poznanie będzie tym lepsze, im ściślej będzie odpowiadało rzeczywistości obecnej”, tenże, „Recenzja pracy W. Biegańskiego Traktat o poznaniu i prawdzie”, Przegląd Filozoficzny 2 (1910): 219.

9 Zob. Marian Borowski, Humanistyczne i empiryczne pierwiastki w nauce (Lwów: Wydawnictwo Polskiego Towarzystwa Filozoficznego, 1913).

10 Tamże, 21.

11 Borowski twierdził, że w zasadzie wyboru uczeni decydują, jakie potrzeby społeczne należy uwzględniać w strukturze wiedzy naukowej. Zasada ekonomii jest realizowana wówczas, gdy najlepsze wyniki naukowe osiąga się przy możliwie najmniejszym nakładzie sił i środków. Trzecia reguła - zasada wyjaśnienia - ujawnia znaczenie metodologii naukowej. Chodzi o konieczność poszukiwania stałych związków i zależności między badanymi faktami - zwłaszcza istnienia związku przyczynowego i celowego. Zasadę pewności realizuje się poprzez dążenia do niepodważalności wiedzy naukowej za sprawą, z jednej strony, licznych doświadczeń oraz, z drugiej strony, wykazywania związku wiedzy naukowej z oczywistymi pewnikami logiki, matematyki i teorii poznania. Piątą, ostatnią zasadą pierwiastka humanistycznego jest tzw. postulat harmonii. Uznaje się na ogół, że względy estetyczne - elegancja koncepcji, jej komplementarność oraz spójność - mają pewne znaczenie w ocenie wartości wiedzy naukowej, tamże, 22-23. 
nych stałych właściwości widocznych w pracy naszego umysłu. Natomiast pierwiastek empiryczny określa przedmiotowy aspekt poznania naukowego, czyli innymi słowy odnosi się do opisu rzeczywistości przyrodniczej i społecznej w jej obiektywnym istnieniu - poza aktualnymi czynnościami poznającego umysłu. Borowski zdaje sobie jednak sprawę, że jest to postulat możliwy do realizacji tylko w pewnym stopniu, ponieważ nasze czynności poznawcze mogą być przecież także przedmiotem analiz i nieuchronnie stają się wówczas jakimś aspektem i składnikiem rzeczywistości przyrodniczej.

Podczas analizy właściwości pierwiastka empirycznego uczony wymienia ponownie pięć zasad, których realizacja jest świadectwem obecności tego składnika w poznaniu naukowym. To reguła przedmiotowości, zasada myślenia bez hipostaz, unikanie konkretyzowania zagadnień oraz reguły prawdy teoretycznej i praktycznej ${ }^{12}$. Co ciekawe, pierwiastek empiryczny może funkcjonować czasem w wyraźnym konflikcie z pierwiastkiem humanistycznym. Borowski pisze, że empiryczna reguła przedmiotowości często koliduje $\mathrm{z},[\ldots]$ humanistycznym postulatem wciągania w zakres badań naukowych tylko tych przedmiotów, które mają dla nas znaczenie i z których opanowania wiedzą można spodziewać się jakiegoś pożytku”"13. Konflikt ten, aczkolwiek istotny, nie zatrzymuje jednak procesu realizacji celów nauki, jeśli badamy jej historię w dłuższej perspektywie. Borowski zauważa jednak, że w historycznym rozwoju nauki dochodzi czasem do innej deformacji - absolutyzacji jednego z pierwiastków i jednoczesnej marginalizacji drugiego składnika. Tak dzieje się, na przykład, gdy przedmioty poznania naukowego stają się zbyt abstrakcyjnymi pojęciami. Stają się wówczas poznawczymi narzędziami do określania istoty rzeczy i procesów niejako poza kontekstem ich realnego,

12 Zasada przedmiotowości akcentuje znaczenie bezinteresownego ujęcia celów poznania naukowego. Realizując tę zasadę, uczeni nie powinni myśleć o wymiernych, praktycznych zastosowaniach teorii naukowej w życiu społecznym. Unikanie hipostaz jest niezbędne w procesie precyzowania teorii naukowej, a reguła niekonkretyzowania wskazuje na wartość czystości abstrahowania, czyli - innymi słowy - konsekwentnego unikania zbyt obrazowych porównań w poznaniu naukowym. W realizacji zasady prawdy teoretycznej chodzi o to, by w części teoretycznej nauki nie pomijać faktów empirycznych niezgodnych z jej założeniami. Ostatnią zasadą pierwiastka empirycznego jest reguła prawdy praktycznej, w której realizacji uwzględnia się przede wszystkim funkcjonalne walory wiedzy naukowej. Teorie i hipotezy naukowe powinny być tak formułowane, by można je było stosować łatwo i skutecznie, tamże, 23.

13 Tamże, 16. 
społecznego znaczenia. Dochodzi wówczas do racjonalnie nieuzasadnionej absolutyzacji pierwiastka humanistycznego, a tym samym lekceważenia istotnego znaczenia pierwiastka empirycznego. Czasem widoczna jest odwrotna deformacja, gdy w argumentacji naukowej „[...] akcentuje się postulat zgodności wiedzy naukowej z materiałem faktów, a pozostawia w cieniu postulat drugi, aby nauka odpowiadała potrzebom i organizacji człowieka"14. $\mathrm{W}$ takim zniekształconym rozumieniu zadań nauki nadmiernie dominującym pierwiastkiem okazuje się wówczas składnik empiryczny.

W tej rozprawie Borowski przedstawia też kilka interesujących uwag na temat pewnych kwestii metodologicznych istotnych w pracy naukowej. W szczególności analizuje możliwe znaczenia terminu „wyjaśnienie”. Podkreśla, że wyjaśnienie jest czynnością umysłową, w której uznajemy logiczny związek tożsamości dwóch stanów rzeczy. W wyjaśnieniu chodzi zatem o to, by opis określanego zjawiska uzależnić od procesu czy zjawiska bardziej znanego. Borowski wymienia trzy podstawowe sposoby opisu rzeczywistości, które uznaje za wyjaśnienia naukowe. Można w argumentacji naukowej szukać przyczyn danych faktów albo wskazywać na cel, do którego dane zjawisko zmierza. Istnieje także możliwość wyjaśnienia obserwowanych procesów poprzez analizę ich historii i genezy. Wyjaśnienie ujawnia więc - w obszarze analizowanych zjawisk - istnienie zależności przyczynowej, teleologicznej lub genetycznej. Borowski podkreśla jednak, że w wyjaśnieniu naukowym trzeba dążyć do maksymalnie abstrakcyjnego ujęcia badanych zależności. Wprawdzie, jak zauważa, pewna „[...] obrazowość teorii może być pożyteczna w heurystycznej (empirycznej) części nauki. Obraz ułatwia zwrócenie uwagi na pewne stosunki w zjawiskach obserwowanych. Ale obraz ten należy, jako rusztowanie pomocnicze, odrzucić przy ostatecznym formułowaniu teorii"15.

Nie ulega wątpliwości, że „Humanistyczne i empiryczne pierwiastki w nauce" to rozprawa potwierdzająca dojrzałość badawczą Borowskiego. Widoczna jest ona nie tylko w intrygujących pomysłach dotyczących specyfiki poznania naukowego, ale przede wszystkim we wnikliwości i precyzji jego analiz. Rozprawa owa nie była jednak ostatnią pracą dotyczącą problemów

14 Tamże, 3.

15 Tamże, 19. 
poznania naukowego, aczkolwiek późniejsze, nieliczne wzmianki na ten temat nie są już tak wnikliwe. Borowski wypowiada się bowiem o problemach nauki raczej w formie krótkich uwag i komentarzy, które przedstawia podczas analizy innych kwestii.

W pracy „O rozwoju życia psychicznego”, opublikowanej w końcu roku 1913, Borowski odnosi się ponownie do zależności między pierwiastkiem humanistycznym i empirycznym. Tym razem jednak akcentuje konieczność osiągania harmonii między tymi składnikami - wartość syntezy tych pierwiastków w każdej formie aktywności badawczej. „W nauce i działalności praktycznej - podkreśla - liczyć się należy z jednej strony z człowiekiem, jego psychofizyczną organizacją, potrzebami, ideami - nazwijmy to pierwiastkiem humanistycznym - a z drugiej strony z faktami, z doświadczeniem, jakością tego materiału, w którym człowiek działa i usiłuje przekształcić stosownie do swojej organizacji i swoich potrzeb - a więc z pierwiastkiem empirycznym"16.

Ostatnia uwaga Borowskiego o istocie poznania naukowego pojawia się w roku $1922 \mathrm{w}$ artykule pt. „Instynkt, intelekt, intuicja” ${ }^{17}$. Kwestie dotyczące istoty poznania naukowego są tutaj analizowane w perspektywie historycznej, a ściślej - w kontekście docelowego statusu nauki w strukturze wiedzy ludzkiej. Patrząc retrospektywie na historię nauki, Borowski dostrzega istnienie stałej tendencji w jej rozwoju, która także ujawnia się w innych istotnych składnikach kultury - sztuce, religii, filozofii czy literaturze. Człowiek w swojej aktywności poznawczej ogranicza bowiem konsekwentnie udział reakcji i czynności instynktownych na rzecz aktywności intelektualnej, a w dalszej przyszłości obydwa systemy orientacji w świecie - instynktowny i intelektualny - zostaną syntetycznie połączone w poznaniu intuicyjnym. Borowski sądził, że ogląd intuicyjny stanie się niebawem najlepszym narzędziem naukowego poznania rzeczywistości.

${ }^{16}$ Marian Borowski, „O rozwoju życia psychicznego”, Poradnik dla samouków. Świat i człowiek 5, 3 (1913): 216.

17 Marian Borowski, „Instynkt, intelekt, intuicja”, Przegląd Filozoficzny 2 (1922): 197-227. 
Nie ulega wątpliwości, że sposób, w jaki Borowski rozumiał specyfikę poznania naukowego, był w dużym stopniu kształtowany przez dyskusje na temat fenomenu nauki, odbywające się w lwowskim środowisku filozoficznym. Myślę przede wszystkim o fundamentalnym znaczeniu seminarium filozoficznego, stworzonego w roku 1897 przez Kazimierza Twardowskiego, w którym Borowski uczestniczył już w okresie studiów. Przypomnijmy, że Twardowski uznawał zagadnienia filozoficzne za istotne także dla poszczególnych nauk przyrodniczych i humanistycznych ${ }^{18}$. Takie ujęcie związków merytorycznych oraz metodologicznych pomiędzy filozofią i poszczególnymi naukami dostrzec można także w analizach Mariana Borowskiego.

Proponowana przez Twardowskiego koncepcja nauki inspirowała również Borowskiego w nieco innym aspekcie. Filozof zgadzał się bowiem z jego przekonaniem, że znaczenie pojęcia prawdy w rozważaniach filozoficznych, a zwłaszcza metafizycznych, nie jest takie samo jak sens terminu „prawda” w kontekście uwarunkowań poznania naukowego. W roku 1929 Twardowski stwierdza, że $[\ldots]$ naukowe ujęcie prawd, tkwiących w systemach metafizycznych, nie może być dokonywane ze stanowiska naukowego poglądu na świat i życie, gdyż takiego poglądu nie posiadamy; toteż dokonują go poszczególne nauki specjalne, stosownie do swojego zainteresowania w danym

${ }_{18}$ W notatkach z roku 1898 Twardowski tak określa najważniejsze cele badawcze swojego seminarium: „Samodzielny sąd na polu filozofii. To potrzebne każdemu człowiekowi wykształconemu, a przede wszystkim każdemu o wykształceniu akademickim. [...] Prawnik: jeśli naukowo chce pracować, to filozofia potrzebna. Rozwój pojęć prawniczych z filozoficznymi związany, a sam rozwój i początek prawa, poczucie prawa, to rzecz psychologii zbiorowej. [...] Lekarz: ma do czynienia z psychologią, i to nie tylko psychiatra. Musi więc znać teorie, musi się w nich orientować. Dalej kwestia etyki lekarskiej, w ostatnich latach podnoszona. Następnie liczne teorie biologiczne, fizjologiczne, które wymagają znajomości poglądów i krytyki filozoficznej. Na koniec słuchacze wydziału filozoficznego. Oddają się poszczególnym naukom, ale nie ma takiej, która by nie pozostawała w związku z filozofią. Wszak dla każdej nauki logika organonem. W każdej nauce hipotezy i teorie. Każda nauka była lub jest pod wpływem pewnych poglądów filozoficznych”, w: Kazimierz Twardowski, „Wstęp do seminarium filozoficznego niższego" (Warszawa: Archiwum Kazimierza Twardowskiego w zbiorach Archiwum Cyfrowego Połączonych Bibliotek UW, IFiS PAN i PTF, nr spisu inw. [P.18,3], 1898), 1-2. 
zagadnieniu, w danym pojęciu, w danym twierdzeniu"19. Innymi słowy, dla Twardowskiego podstawowe cele poznania naukowego są wprawdzie także przedmiotem refleksji filozofów, niemniej w poszczególnych naukach cele te są definiowane $\mathrm{w}$ ścisłym związku $\mathrm{z}$ zakresem ich kompetencji badawczych. Podobnie rozumuje Borowski, aczkolwiek silniej podkreśla znaczenie problematyki filozoficznej w strukturze poznania naukowego, a zwłaszcza w jego części systematycznej (teoretycznej) ${ }^{20}$.

Warto zauważyć, że w dążeniach Borowskiego do zdefiniowania istoty nauki ujawnia się także wyraźnie podobieństwo do propozycji Adama Mahrburga, który publikował swoje analizy dotyczące istoty nauki już na przełomie XIX i XX wieku. Wspólnie podkreślali, że poznanie naukowe musi mieć konsekwencje praktyczne i powinno uwzględniać ważne potrzeby społeczne. Mahrburg, akcentując wartość tego społecznego kontekstu funkcjonowania nauki, stwierdzał, że wszelką rzetelną argumentację naukową można przedstawić w następującym schemacie wnioskowania: „pierwszą przesłankę stanowi potrzeba, [...] w ogóle - cel jednostki, grupy jednostek lub wszystkich ludzi; [...] drugą, właściwie naukową przesłankę stanowi możliwie dokładna informacja o warunkach rzeczywistych lub przewidywalnych, wobec których ma się stać zadość wyrażonej w pierwszej przesłance potrzebie, pożądaniu lub wymaganiu. [...] Na koniec wniosek stanowi rozwiązanie wskazujące, co należy czynić, by cel osiągnąć, o ile takie rozwiązanie jest możliwe ze względu na stan nauki lub na treść wymagań pierwszej przesłanki. Nauka w tym schemacie występuje jako ogniwo pośredniczące między celem życia a przewidywanym ziszczeniem go"21.

Wydaje się, że Mahrburg, a w ślad za nim także Borowski, byli zwolennikami takiej koncepcji nauki, którą - u schyłku XIX stulecia - w przybliżeniu określał termin „scjentyzm pozytywistyczny”. W tym ujęciu istota poznania naukowego ujawnia się $\mathrm{w}$ dążeniu do metodycznego opisu treści wrażeń

19 Kazimierz Twardowski, „Przemówienie wygłoszone na obchodzie dwudziestopięciolecia Polskiego Towarzystwa Filozoficznego we Lwowie dnia 12 lutego 1929 roku" (Lwów: Księga Pamiątkowa Polskiego Towarzystwa Filozoficznego, 1931), cyt. za: Lwowsko-warszawska szkoła filozoficzna. Wybór tekstów, red. Krzysztof Szlachcic (Wrocław: Wydawnictwo Uniwersytetu Wrocławskiego, 1984), 18.

20 Borowski, Humanistyczne i empiryczne pierwiastki w nauce, 21.

21 Adam Mahrburg, „Co to jest nauka?”, Przegląd Filozoficzny 1 (1897/1898): 22. 
zmysłowych. Innymi słowy, w owym „scjentyzmie pozytywistycznym” wiedza naukowa to raczej rezultat określonego procesu poznawczego - konsekwencja intelektualnej interpretacji danych doświadczanych w poznaniu zmysłowym ${ }^{22}$.

Analizując refleksję Borowskiego dotyczącą specyfiki nauki oraz wyraźną zależność jego koncepcji od propozycji Twardowskiego i Mahrburga, warto zauważyć, że ostateczny, dojrzały kształt jego teorii nauki był także wynikiem określonego klimatu intelektualnego, który ukształtował się w kulturze europejskiej u schyłku wieku XIX. W tej atmosferze zwiększał się wyraźnie autorytet wiedzy naukowej i poznania metodycznego, zwłaszcza w kontekście większych możliwości opisu struktury rzeczywistości przyrodniczej i społecznej. Co tworzyło ów nowy ideał nauki? Myślę, że warto przypomnieć jego trzy podstawowe składniki. Pierwszy element tej teorii to przekonanie, że poznanie naukowe nie przeciwstawia się bezwzględnie myśleniu filozoficznemu, jako że istotny zakres problematyki filozoficznej to także zagadnienia stricte naukowe. Konsekwencja takiego sposobu myślenia była oczywista: uznano, że w koncepcji filozofii naukowej - kwestionującej wartość poznawczą metafizycznych spekulacji - ujawnia się najlepiej specyfika myślenia filozoficznego. Drugi składnik uwidocznił się w tendencji do kwestionowania kompetencji naukowej teologii jako wiedzy o zjawiskach nadprzyrodzonych, irracjonalnych, a zatem $\mathrm{z}$ istoty nienaukowych. To stanowisko niekoniecznie prowadziło do negowania wartości i znaczenia religii w życiu społecznym człowieka. Natomiast trzeci aspekt tego nowego ideału nauki zawierał się w tezie, że wzorem ścisłości metodologicznej dla rozmaitych dziedzin wiedzy naukowej są przede wszystkim nauki przyrodnicze. To był pogląd

22 Określeniem „scjentyzm pozytywistyczny” w odniesieniu do koncepcji Mahrburga posługiwał się też Włodzimierz Tyburski. Zwrócił uwagę, że jego rozumienie zadań nauki w ostatniej dekadzie wieku XIX było propozycją metodologicznie dojrzałą i różniło się wyraźnie „[...] od tych postaci nauki, które propagował ruch pozytywistyczny u zarania swego rozwoju. [...] W latach dziewięćdziesiątych akceptowano empiryzm, ale nie jego skrajną, naiwną postać, lecz posiłkowany analizą podmiotowych form doświadczenia. Przedmiot poznania to nie tylko nagi fakt, lecz także intelektualna organizacja materii doświadczenia”, w: Włodzimierz Tyburski, Ideologia nauki w świadomości polskich środowisk intelektualnych doby pozytywizmu. Rozwój - metamorfozy - załamania (Toruń: Wydawnictwo Uniwersytetu Mikołaja Kopernika, 1989), 205-206. 
wzmocniony przekonaniem o wielkiej doniosłości wyników osiąganych ówcześnie w naukach przyrodniczych.

W polskich realiach życia naukowego na przełomie XIX i XX wieku ów ideał nauki realizował w dużym stopniu warszawski Przegląd Filozoficzny, który powstał w efekcie współpracy Władysława Weryhy i Kazimierza Twardowskiego. Był to pierwszy polski periodyk, którego redakcja, w swoich deklaracjach ideowych, akcentowała konieczność podejmowania istotnych problemów filozoficznych w ścisłym związku z zagadnieniami stricte naukowymi. Przywołuję działania Weryhy i kolejnych redakcji Przeglądu Filozoficznego na przełomie wieku XIX i XX, ponieważ Marian Borowski wielokrotnie publikował swoje prace $\mathrm{w}$ tym czasopiśmie, był także jego redaktorem naczelnym i niewątpliwie akceptował założenia koncepcji nauki oraz filozofii naukowej popularyzowanej przez kolejnych redaktorów kierujących Przeglądem ${ }^{23}$.

Mówiąc ściśle, nowy ideał nauki i filozofii naukowej miał realizować określony typ badacza, który jednocześnie będzie specjalistą, autorytetem w określonej dyscyplinie naukowej, a zarazem filozofem kompetentnym w zakresie teorii poznania naukowego. „Tacy ludzie - pisał Weryho - jak: Du Bois-Reymond, Helmholtz, Huxley, Tyndall, Wundt, Mach - są to znakomici specjaliści, a jednocześnie przedstawiciele dzisiejszej filozofii”24. Kilka lat później, w opisie nowej inicjatywy wydawniczej redakcji Przeglądu Filozoficznego, ten postulowany wzorzec poznania naukowego został doprecyzowany. W niepodpisanym prospekcie, informującym wstępnie o planowanych przekładach na język polski ważnych prac naukowych, czytamy, że: „Rozwój

${ }^{23}$ Warto zauważyć, że Borowski to jeden z czterech redaktorów naczelnych Przeglądu Filozoficznego w okresie jego istnienia, tzn. w latach 1897-1949. Pierwszym redaktorem był Władysław Weryho - założyciel periodyku - a po nim czasopismem kierowali kolejno: Jan Łukasiewicz, Marian Borowski i Władysław Tatarkiewicz.

${ }^{24}$ Władysław Weryho, „Słowo wstępne”, Przegląd Filozoficzny 1 (1897/1898): 5. „Specjalizacja badań naukowych - pisał w nim wówczas - rozdrobnienie pracy wymaga przede wszystkim drobiazgowego opracowania szczegółów, tych cegiełek, z których wznosi się gmach wiedzy ludzkiej. Ażeby jednak z pożytkiem pracować nad szczegółami i zdawać sobie sprawę $\mathrm{z}$ narzędzi, którymi się posługujemy przy badaniu, to jest $\mathrm{z}$ pojęć i metod używanych $\mathrm{w}$ naukach poszczególnych, to temu zadość czyni filozofia, w której zakres wchodzi uogólnienie syntetyczne, roztrząsanie zależności wzajemnej różnych specjalnych dziedzin nauki, krytyka pojęć i metod", tamże, 1-2. 
filozofii współczesnej, tej przynajmniej, która pozostaje w żywym stosunku działań i odziaływań z naukami w ogóle i sama z zasady poczuwa się do obowiązku karności naukowej, posuwa się w kierunku dwóch osi kardynalnych: nowokrytycyzmu i ewolucjonizmu. Ciecz macierzystą, w której odbywa się ta dwuosiowa krystalizacja, stanowi nauka, rozważana na tle rozwoju wiedzy w ogóle i psychologia doświadczalna, na biologicznych podstawach oparta”25.

Warto zauważyć, że w tym manifeście ideowym zakresy zainteresowań poznawczych filozofii oraz poszczególnych nauk nie stanowią już odrębnych pól kompetencyjnych, ale ujawniają $\mathrm{w}$ istocie istnienie wspólnego kontekstu badań. Nowokrytycyzm - inspirując się niedogmatycznie założeniami Kantowskiej teorii poznania - ma być właśnie teorią nauki, czyli dostarczać narzędzia do opisu specyfiki poznania naukowego. Nie ulega wątpliwości, że dla autorów prospektu to jest właśnie podstawowe zadanie filozofii - pytać krytycznie o aprioryczne i aposterioryczne pierwiastki istniejące w strukturze i metodach poznania naukowego. Ewolucjonizm natomiast miał ujawniać, w ciągłych odniesieniach do założeń nowokrytycyzmu, znaczenie genetycznego aspektu w rozmaitych teoriach rozwoju wiedzy ludzkiej, zwłaszcza jego roli w historii nauki i filozofii. Wydaje się, że ewolucjonizm nie jest bynajmniej tutaj tylko jednym ze stanowisk teoretycznych w filozofii europejskiej wieku XIX, ale fundamentalnym pierwiastkiem obecnym w każdej historycznej formie namysłu filozoficznego. Zawsze bowiem istnieje potrzeba określenia znaczenia i proporcji składników irracjonalnych i racjonalnych, kształtujących w poszczególnych okresach historii kultury tożsamość filozofii i nauki. Najczęściej przedstawiano wówczas te zależności w popularnej koncepcji trzech etapów rozwoju wiedzy (instynkt-intelekt-intuicja).

Trzeba jednak podkreślić, że Borowski, który mieszkał Warszawie od roku 1918, i w rezultacie związał się wtedy silniej z warszawskim środowiskiem naukowym, był jednak myślicielem ukształtowanym w intelektualnym klimacie etosu badawczego tworzonego wytrwale przez Kazimierza Twardowskiego. Fakt ten miał wymierne konsekwencje w każdym z etapów działalności twórczej Borowskiego, także w latach 1919-1923, kiedy był redaktorem naczelnym Przeglądu Filozoficznego. Okazuje się bowiem, że koncepcja nauki, popularyzowana przez kolejnych redaktorów Przeglądu, nie była teorią,

\footnotetext{
25 Prospekt Wydawnictwa, Przegląd Filozoficzny 1 (1901): 1.
} 
z której założeniami Borowski utożsamiał się w pełni. Filozof podzielał wszak przekonanie Twardowskiego, że istnieją specyficzne nauki filozoficzne m.in. metafizyka, teoria poznania, etyka, psychologia, logika - których zakres kompetencji nie jest identyczny z przedmiotem zainteresowań badawczych poszczególnych nauk specjalnych - humanistycznych, przyrodniczych, technicznych czy formalnych. Najwięcej kwestii spornych pojawiało się w próbach określenia, w kryteriach poznania naukowego, celów badawczych metafizyki, etyki czy psychologii. Borowski, podobnie jak Twardowski, nie widział sensownej możliwości stworzenia metafizyki naukowej i w tym kontekście rzeczywiście akceptował założenia scjentyzmu pozytywistycznego. Z drugiej strony nie chciał jednak zupełnie kwestionować wartości tradycyjnego poznania metafizycznego (spekulatywnego), a także sensowności uprawiana metafizyki w myśl założeń filozofii Brentana, czyli jako refleksji o przedmiotach doświadczenia wewnętrznego (introspekcja).

Warto zauważyć, że Borowski, będąc w okresie międzywojennym aktywnym uczestnikiem warszawskiego życia filozoficznego, poszukiwał konsekwentnie szerszego kontekstu problemowego, w którym wielki potencjał naukowych zagadnień, ujawniający się w dziejach europejskiej metafizyki, stanowiłby zarazem wspólny przedmiot zainteresowań badawczych filozofii oraz poszczególnych nauk. Realizacją tego zadania była niewątpliwie koncepcja filozofii całości przedstawiona w roku $1930 \mathrm{w}$ obszernym artykule ${ }^{26}$. W tej pracy - ostatnim większym tekście Borowskiego o znaczeniu filozoficznym uczony wnikliwie analizuje merytoryczne związki pomiędzy problematyką badań filozoficznych i dociekań stricte naukowych. Dochodzi do wniosku, że zasadniczym przedmiotem badań filozoficznych, a także poszczególnych nauk, są w istocie struktury i formy pojawiające się w rozwoju rzeczywistości przyrodniczej i społecznej. Co istotne, znaczenie tych struktur - nazywanych przez filozofa całościami - można zrozumieć tylko w kontekście istnienia rozmaitych potrzeb człowieka ${ }^{27}$. Koncepcja filozofii całości wydaje się więc

26 Zob. Marian Borowski, „Konspekt filozofii całości”, Przegląd Filozoficzny 1-2 (1930): 196-232.

27 Borowski podkreślał w „Konspekcie...”, że dążenie do „ [...] coraz to wyższej organizacji cechuje cały świat istot żywych. W tym kierunku zmierzają też wszystkie ludzkie ideały. Tak więc etyka zajmuje się porządkowaniem, konsekwencją, zjednoczeniem i wydajnością naszych czynów i dążeń, tak indywidualnych, jak i całych grup społecznych. Organizacją naszej 
stanowiskiem kompromisowym, uwzględniającym niektóre tezy scjentyzmu pozytywistycznego i jednocześnie, pozostając pod wyraźnym wpływem poglądów Kazimierza Twardowskiego, jego przekonanie o specyfice badawczej nauk filozoficznych.

Warto pamiętać, że istotnym aspektem koncepcji filozofii całości były wszechstronne analizy ludzkich czynów, które Borowski definiował także jako pewne złożone całości. Te rozważania - zapoczątkowane przez filozofa w roku 1923 - stanowią w jego działalności twórczej osobny, istotny składnik; na tyle ważny, że można uznać Borowskiego, obok Tadeusza Kotarbińskiego, za prekursora badań prakseologicznych w Polsce. Nie analizowałem jednak szczegółowo założeń jego koncepcji czynu, gdyż przedmiotem moich rozważań była specyfika poznania naukowego. Natomiast analiza ludzkich działań w myśli Borowskiego to raczej nauka pomocnicza do badania problemów stricte filozoficznych - ontologicznych, metodologicznych czy etycznych ${ }^{28}$.

Podsumowując, sądzę, że jego refleksję na temat specyfiki poznania naukowego można określić jako swoisty, ideowy łącznik między założeniami koncepcji nauki przekazywanej przez Twardowskiego swoim uczniom w lwowskim środowisku filozoficznym a ujęciem istoty nauki proponowanym w środowisku warszawskich badaczy, czyli tej społeczności, w której działał Borowski w dojrzałym okresie swojej pracy naukowej. Trwałym składnikiem

wrażliwości zmysłowej i pełni wewnętrznego odczuwania i przeżywania zajmują się sztuki piękne. W ekonomii dążymy do lepszego zorganizowania pracy, produkcji, rozdziału dóbr, do lepszego wyzyskania i wzajemnego przystosowania wszystkich czynników gospodarczych. Nauka i filozofia starają się ująć nasze doświadczenie jako pewną, związaną i niesprzeczną całość, w której nie byłoby niczego przypadkowego i w której wszystkie części dałoby się zrozumieć z jednej lub niewielu zasad", tamże, 210.

28 Zob. Marian Borowski, „Aktywizm i pasywizm”, Przegląd Filozoficzny 1 (1923): 90-99; tegoż, „O składnikach czynu”, Przegląd Filozoficzny 3-4 (1923): 144-159; tegoż, „O rodzajach czynu”, Przegląd Filozoficzny 1 (1924): 37-64; tegoż, „O zakresie pojęcia czynu” (Warszawa: Księga Jubileuszowa dla uczczenia 40-letniej pracy naukowej Ludwika Krzywickiego, 1925): 3-15; tegoż, „O składnikach i rodzajach czynów” (Streszczenie referatu pt. „Klasyfikacja czynów” wygłoszonego w roku 1923 na I Polskim Zjeździe Filozoficznym we Lwowie), Przegląd Filozoficzny (1927): 275-277; tegoż, „Kilka uwag o wzajemnym stosunku etyki i psychologii”, Przegląd Filozoficzny 4 (1928): 368-384. Zob. także: Dariusz Barbaszyński, „Refleksja prakseologiczna Mariana Borowskiego”, Studia z Filozofii Polskiej 2 (2007): 39-57; tegoż, „Uwarunkowania czynu ludzkiego w analizach Mariana Borowskiego", w: O skuteczności myślenia, red. Agnieszka Biegalska, Mieczysław Jagłowski (Olsztyn: Logos i Praxis, 2010), 77-88. 
refleksji Borowskiego było przekonanie, że kontekst badań filozoficznych realizowanych $\mathrm{w}$ doświadczeniu zewnętrznym oraz wewnętrznym - jest zawsze szerszy niż perspektywa, w której ujawniają się cele poznania naukowego. W dążeniach filozoficznych istotne są bowiem również kwestie światopoglądowe, a co za tym idzie - ważne są także mniej racjonalne składniki poznania, takie jak emocje czy uczucia. Natomiast z założeń szeroko rozumianego „scjentyzmu pozytywistycznego" Borowski przejął niewątpliwie tezę o znaczeniu procesów ewolucyjnych w rozwoju wiedzy ludzkiej, która w swojej coraz bardziej skomplikowanej strukturze staje się właśnie nauką lub filozofią rozumianą jako teoria nauki.

\section{Bibliografia}

Avenarius Richard. 1888-1890. Kritik der reinen Erfahrung. vols. 1 und 2. Leipzig: Verlag.

Barbaszyński Dariusz. 2007. „Refleksja prakseologiczna Mariana Borowskiego”. Studia z Filozofii Polskiej 2: 39-57.

Barbaszyński Dariusz. 2010. „Uwarunkowania czynu ludzkiego w analizach Mariana Borowskiego". W: Logos i Praxis. O skuteczności myślenia, red. Agnieszka Biegalska, Mieczysław Jagłowski. Olsztyn: Wydawnictwo UWM.

Barbaszyński Dariusz. 2012. Odkrywanie struktur rzeczywistości. Problemy filozofii całości w pogladach Mariana Borowskiego. Olsztyn: Wydawnictwo UWM.

Borowski Marian. 1904. „Czy jednakowe skutki mogą być wywołane różnymi przyczynami?". Przegląd Filozoficzny 1: 105.

Borowski Marian. 1907. „Krytyka pojęcia związku przyczynowego”. Przegląd Filozoficzny 4: 492-508.

Borowski Marian. 1910. „O filozofii Ryszarda Avenariusa”. Widnokreggi 17: 130-134; 18: 172-175; 19: 196-204.

Borowski Marian. 1910. „Recenzja pracy W. Biegańskiego Traktat o poznaniu i prawdzie". Przeglad Filozoficzny 2: 219.

Borowski Marian. 1913. Humanistyczne i empiryczne pierwiastki w nauce. Lwów: Wydawnictwo PTF.

Borowski Marian. 1913. „O rozwoju życia psychicznego”. Poradnik dla samouków. Świat i człowiek 5, 3: 216. 
Borowski Marian. 1914. „Recenzja pracy W. Kozłowskiego Systemat wiedzy i klasyfikacja nauk jako wstęp do wykształcenia ogólnego". Książka. Miesięcznik poświęcony krytyce i bibliografii polskiej 3: 138-139.

Borowski Marian. 28 marca 1916. „Ernest Mach”. Gazeta Wieczorna.

Borowski Marian. 1922. „Instynkt, intelekt, intuicja”. Przeglad Filozoficzny 2: 197-227.

Borowski Marian. 1923. „Aktywizm i pasywizm”. Przeglad Filozoficzny 1: 90-99.

Borowski Marian. 1923. „O składnikach czynu”. Przeglad Filozoficzny 3-4: 144-159.

Borowski Marian. 1924. „O rodzajach czynu”. Przeglad Filozoficzny 1: 37-64.

Borowski Marian. 1925. „O zakresie pojęcia czynu”. W: Księga Jubileuszowa dla uczczenia 40-letniej pracy naukowej Ludwika Krzywickiego. Warszawa.

Borowski Marian. 1927. „O składnikach i rodzajach czynów” (Streszczenie referatu pt. „Klasyfikacja czynów” wygłoszonego w roku 1923 na I Polskim Zjeździe Filozoficznym we Lwowie). Przegląd Filozoficzny 4: 275-277.

Borowski Marian. 1928. „Kilka uwag o wzajemnym stosunku etyki i psychologii”. Przeglad filozoficzny 4: 368-384.

Borowski Marian. 1930. „Konspekt filozofii całości”. Przegląd Filozoficzny 1-2: 196-232.

Mahrburg Adam. 1897-1898. „Co to jest nauka”. Przeglad Filozoficzny 1: 22.

Prospekt Wydawnictwa. 1901. Przegląd Filozoficzny 1: 1.

Szlachcic Krzysztof. 1984. Lwowsko-warszawska szkoła filozoficzna. Wybór tekstów. Wrocław: Wydawnictwo UWr.

Twardowski Kazimierz. 1898. Wstęp do seminarium filozoficznego niższego. Warszawa: Archiwum Kazimierza Twardowskiego w zbiorach Archiwum Cyfrowego Połączonych Bibliotek UW, IFiS PAN i PTF, nr spisu inw. [P.18.3].

Twardowski Kazimierz. 1912. „Nauki humanistyczne a psychologia” (Autoreferat z odczytu wygłoszonego we Lwowie w dniu 12 października $1912 \mathrm{r}$. na posiedzeniu Polskiego Towarzystwa Filozoficznego). Ruch Filozoficzny 9.

Twardowski Kazimierz. 1921-1922. „Symbolomania i pragmatofobia” (Odczyt wygłoszony na 216 posiedzeniu naukowym Polskiego Towarzystwa Filozoficznego dnia 5 marca 1921 roku). Ruch Filozoficzny 6, 1-2: 1-10.

Twardowski Kazimierz. 1931. „Przemówienie wygłoszone na obchodzie dwudziestopięciolecia PTF we Lwowie w dniu 12 lutego 1929 r." W: Księga Pamiątkowa Polskiego Towarzystwa Filozoficznego. Lwów: Wydawnictwo PTF.

Tyburski Włodzimierz. 1989. Ideologia nauki w świadomości polskich środowisk intelektualnych doby pozytywizmu. Rozwój - metamorfozy - załamania. Toruń: Wydawnictwo UMK.

Weryho Władysław. 1897/1899. „Słowo wstępne”. Przegląd Filozoficzny 1: 1-2, 5. 


\section{Abstract}

\section{The Nature of Scientific Cognition in the Thought of Marian Borowski}

The article presents the approach of Marian Borowski to the nature of scientific cognition. It points to the dependence of his views on the assumptions of the theory of science proposed by Kazimierz Twardowski, the founder of the Lvov-Warsaw School. It is also emphasized that Borowski's approach was largely reminiscent of the concept of science shaped at the turn of the $19^{\text {th }}$ and $20^{\text {th }}$ centuries by representatives of the Warsaw scientific milieu. When it comes to the presented issues, Przeglad Filozoficzny (Philosophical Review) was a central periodical which published works on the nature of scientific cognition. Such inspirations are visible in Borowski's detailed analyses on the nature of science, considering its cognitive competences, methodological problems and issues related to the structure of scientific knowledge. The article presents the matter of mutual relationships, both methodological and subject-matter-related, between philosophy and science. Developing Twardowski's theory of science, Borowski believed it was possible to pursue scientific philosophy. It is also emphasized, however, that at the same time he recognized a certain research autonomy of philosophy in relation to the tasks and aims of particular humanities and natural sciences.

Keywords: Lvov-Warsaw School, science, philosophy, structure of scientific cognition, methodology 